\title{
Diversity of aphids (Hemiptera: Aphididae) associated with potato crop in Tizi-Ouzou (North of Algeria), with new records
}

\author{
Samia AIT AMAR ${ }^{1,2}$ and Karima BENOUFELLA-KITOUS ${ }^{1}$
}

Received July 08, 2020; accepted December 14, 2020.

Delo je prispelo 08. julija 2020, sprejeto 14. decembra 2020.

Diversity of aphids (Hemiptera: Aphididae) associated with potato crop in Tizi-Ouzou (North of Algeria), with new records

Abstract: Aphids are among the phytophagous pests that cause serious damage to crop plants. In Northern Algeria, we have little information on their diversity. In this context, the study of the diversity of aphids was carried out in three regions of Tizi-Ouzou (North of Algeria) namely Tizi-Ouzou center, Tizi-Rached and Aghribs on the potato crop using yellow traps. The results showed a total richness of 65 aphid species, divided into 36 genera, 9 tribes and 8 sub-families, of which 11 species were identified for the first time in Algeria. These are Aphis coreopsidis (Thomas, 1878), Capitophorus hippophae (Walker, 1852), Cavariella theobaldi (Gillette \& Bragg, 1918), Hyadaphis coriandri (B. Das, 1918), Macrosiphoniella linariae (Koch, 1855), Monelliopsis pecanis Bissell, 1983, Myzus hemerocallis Takahashi, 1921, Pseudoregma panicola (Takahashi, 1921), Rhopalosiphoninus staphyleae (Koch, 1854), Schizaphis eastopi Van Harten \& Ilharco, 1971 and Ovatus inulae (Walker, 1849). The field located in the center of Tizi-Ouzou is the richest with 55 species, followed by the field of Tizi-Rached with 30 species, and 24 species have been recorded in Aghribs. During the sampling season, Hyperomyzus lactucae (Linnaeus, 1758) and Brachycaudus helichrysi (Kaltenbach, 1843) are the most abundant species with $24.44 \%$ and $21.8 \%$ respectively. Three aphid species have been observed on potato leaves, namely Macrosiphum euphorbiae (Thomas, 1878), Aphis gossypii Glover, 1877 and Myzus persicae (Sulzer, 1776). The latter species was observed in all three study regions.

Key words: aphids; diversity; potato; new species
Pestrost listnih uši (Hemiptera: Aphididae) v nasadih krompirja na območju Tizi-Ouzou (Severna Alžirija) z novimi najdbami

Izvleček: Listne uši so med rastlinojedimi škodljivci tisti, ki lahko povzročijo občutne poškodbe na gojenih rastlinah. V severni Alžiriji je o njihovi pestrosti malo znanega. Z ozirom na to je bila izvedena raziskava pestrosti listnih uši na treh območjih Tizi-Ouzou Severne Alžirije in sicer v središču območja Tizi-Ouzou, in na območjih Tizi-Rached in Aghribs v nasadih krompirja $z$ uporabo rumenih pasti. Izsledki so pokazali, da je celokupna pestrost obsegala 65 vrst listnih uši, ki so pripadale 36 rodovom, 9 plemenom in 8 poddružinam, od katerih je bilo 11 vrst novih za Alžirijo. Te vrste so bile Aphis coreopsidis (Thomas, 1878), Capitophorus hippophae (Walker, 1852), Cavariella theobaldi (Gillette \& Bragg, 1918), Hyadaphis coriandri (B. Das, 1918), Macrosiphoniella linariae (Koch, 1855), Monelliopsis pecanis Bissell, 1983, Myzus hemerocallis Takahashi, 1921, Pseudoregma panicola (Takahashi, 1921), Rhopalosiphoninus staphyleae (Koch, 1854), Schizaphis eastopi Van Harten \& Ilharco, 1971 in Ovatus inulae (Walker, 1849).Polje v središču območja Tizi-Ouzou je vrstno najbogatejše s 55 vrstami, sledi mu polje na območju Tizi-Rached s 30 vrstami in območje Aghribs s 24 vrstami. Med vzorčenjem sta bili vrsti Hyperomyzus lactucae (Linnaeus, 1758) in Brachycaudus helichrysi (Kaltenbach, 1843) najpogostejši s $24,44 \%$ in $21,8 \%$ deležem. Na listih krompirja so bile opažene tri vrste listnih uši in sicer Macrosiphum euphorbiae (Thomas, 1878), Aphis gossypii Glover, 1877 in Myzus persicae (Sulzer, 1776), slednja je bila opažena ns vseh treh območjih.

Ključne besede: listne uši; pestrost; krompir; nove vrste

1 University of Mouloud Mammeri, Faculty of Biological Sciences and Agronomic Sciences, Animal and Plant Biology Department, Tizi-Ouzou, Algeria, Laboratory of Production, Improvement and Protection of Plants

2 Corresponding author, e-mail: samia.aitamar@ummto.dz 


\section{INTRODUCTION}

The potato (Solanum tuberosum L.), is one of the main food resources in the world. It remains the most consumed vegetable or field crop (Brillaud, 2008; Marchoux, 2008). This crop is subject to many pests, including aphids, they are small sap-sucking insects. The direct damage is caused by these pests to the crop by sap sucking, thus reducing the resources available for growth and development of the plant (Blackman and Eastop, 2000; 2006). However, the most significant damage is caused indirectly by plant pathogenic viruses transmitted by aphids. Myzus persicae Sulzer, for example, is known to be a vector of more than 100 plant viruses (Blackman and Eastop, 2000) including Potato Virus Y (PVY), Potato Leafroll Virus (PLRV) or Cucumber Mosaic Virus (CMV) (Lin et al., 2016; Shi et al., 2016).

Aphids are very widespread, more than 4700 species have been recorded in the world (Remaudière and Remaudière, 1997), among them about 450 aphid species have been identified as pests of cultivated plants (Blackman and Eastop, 2000). At least 220 species have been recorded in sub-Saharan Africa (Autrique and Ntahimpera, 1994). One hundred fifty species have been identified in Morocco (Sekkat, 2015). Aphids in Tunisia are represented by one hundred and three species (Bodenheimer and Swirsky, 1957; Blackman and Eastop, 1994; 2000, 2006; Ben Halima-Kamel, 1991, 1995; Ben Halima Kamel and Ben Hamouda, 1993, 1998, 2004, 2005; Boukhris-Bouhachem et al. 1996; Boukhris-Bouhachem et al., 2007). Ninety nine species are recorded from Egypt (Theobald, 1922; Habib and El Kady, 1961; Darwish, 2009), seventy-three species are listed from Libya (Trotter, 1912; 1914; Damiano, 1961;
1962; Blackman and Eastop, 1994; Ahmeid Al-Nagar, 2000; Ahmeid Al-Najar and Nieto Nefrya, 1998).

The Algerian aphid fauna is known partly (Blackman and Eastop, 1994, 2000, 2006; Laamari and Akkal, 2002; Lamaari et al., 2010, 2013; Hidalgo et al., 2012; Laamari, 2016; Laamari et al., 2016; Benoufella-Kitous et al., 2014a, 2014b, 2016, 2019). In Tizi-Ouzou, we have very little data on aphid diversity (Benoufella-Kitous et al., 2014a, 2014b, 2016, 2019). Hence the objective of this study is to evaluate the diversity and abundance of aphids in three potato fields in Tizi-Ouzou region (Northern Algeria).

\section{MATERIALS AND METHODS}

\subsection{THE STUDY REGION}

This study was carried out in three localities of Tizi-Ouzou (Fig.1) in open field potato crops: The first, Resita variety, was planted on March $03^{\text {rd }}, 2013$, over an area of $3000 \mathrm{~m}^{2}$ is located in Tizi-Ouzou Center $\left(36^{\circ} 43^{\prime} 00^{\prime \prime} \mathrm{N}\right.$ and $\left.4^{\circ} 03^{\prime} 00^{\prime \prime} \mathrm{E}\right)$ at $200 \mathrm{~m}$ altitude. The second, Fabula variety, was planted on December $27^{\text {th }}$, 2016, on an area of $300 \mathrm{~m}^{2}$ is located in Tizi Rached $\left(36^{\circ} 40^{\prime} \mathrm{N}\right.$ and $\left.4^{\circ} 11^{\prime} \mathrm{E}\right)$ at $412 \mathrm{~m}$ altitude and the third, Timate variety, was planted on February $23^{\text {th }}, 2017$, on an area of $250 \mathrm{~m}^{2}$ is located in Aghribs $\left(36^{\circ} 48^{\prime} 08^{\prime \prime} \mathrm{N}\right.$, $4^{\circ} 19^{\prime} 22^{\prime \prime} \mathrm{E}$ ) at an altitude of $800 \mathrm{~m}$.

The fields were sampled during the period from April $2^{\text {nd }}$ to June $18^{\text {th }}, 2013$ for the Resita variety, from February $13^{\text {th }}$ to May $8^{\text {th }}, 2017$ for the Fabula variety and from April $1^{\text {st }}$ to June $3^{\text {rd }}, 2017$ for the Timate variety. The experimental protocol followed for the trapping of winged aphids and the visual control of aphids is that

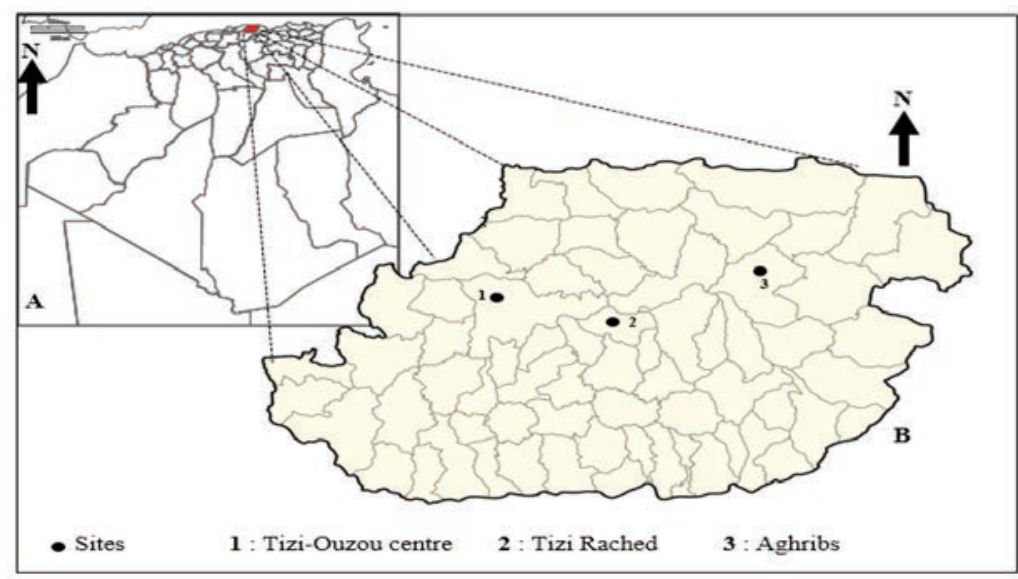

Figure 1: Map of Tizi-Ouzou region and location of study sites, (A) Map of Algeria showing the study region, (B) the study region 
described by Atesebeha et al. (2009). Two methods were combined for monitoring aphidofauna.

\subsection{TRAPPING OF WINGED APHIDS}

To do this, the study field was divided into 9 blocks. In the middle of each block, a yellow Von Moerik trap $(\Theta$ $=27 \mathrm{~cm}, \mathrm{~h}=10 \mathrm{~cm}$ ) was placed, filled with water and a few drops of detergent (dishwashing liquid). The attraction of aphids to the yellow color has been known for long time. This color tends to cause these insects to land (Yattara et al., 2013). The contents of the container are necessary for optimum yield (EDES, 2011). Aphids caught in the yellow traps were removed once a week with a brush and stored in test tubes filled with $70 \%$ ethanol.

\subsection{VISUAL OBSERVATION OF APHIDS ON PO- TATO LEAVES}

Once a week, in each block of the field, one plant was chosen and the aphids found on the potato leaves were collected in a tube filled with $70 \%$ ethanol, using a brush. Aphids trapped and taken from the plants are sorted and then identified up to the species level. According to Lascaux (2010), the identification of aphids was carried out by observing some morphological characters of the aphid, in particular: the antennae, the frontal tubercles, the tarsi, the cauda, the color and the shape of the sphinculi, the pigmentation of the abdomen and venation of the wings. The samples collected were determined by Dr. Benoufella-Kitous at the Plant Production, Improvement and Protection Laboratory of the Faculty of Biological Sciences and Agronomic Sciences at Mouloud Mammeri University in Tizi-Ouzou. The identification was carried out based on the identification keys of Stroyan (1961), Jacky and Bouchery (1982), Autrique and Ntahimpera (1994), Remaudière et al. (1985) and Leclant (1999) and Blackman and Eastop, (2000; 2006).

\section{RESULTS}

During the study, 2144 aphids were collected from all three regions (Table 1). More than two thirds of the catches $(73.27 \%)$ were made in Tizi-Ouzou. A total of 65 species were caught using yellow traps, divided into 36 genera, 9 tribes and 8 subfamilies: Aphidinae, Anoeciinae, Calaphidinae, Chaitophorinae, Eriosomatinae, Hormaphidinae, Myzocallidinae, and Pterocommatinae, 11 species are new to Algeria.

The Aphidinae subfamily is predominant with 2 tribes, that of Aphidini and that of Macrosiphini. The latter is the richest with 39 species. Tizi-Ouzou centre is the richest in species with 55 species, divided into 32 genera, 7 tribes and 5 subfamilies, namely the Aphidinae, Anoeciinae, Calaphidinae, Eriosomatinae and Myzocallidinae. Followed by Tizi Rached station, with 30 species belonging to three subfamilies, namely Aphidinae, Chaitophorinae and Eriosomatinae. Besides, 24 species were recorded at Aghribs belonging to 4 subfamilies, those of Aphidinae, Eriosomatinae, Hormaphidinae, and Pterocommatinae. Considering all stations, the most abundant species during the sampling season are: $\mathrm{Hy}$ peromyzus lactucae (24.44\%), Brachycaudus helichrysi (21.8 \%), Macrosiphum rosae (19.93\%) and Myzus persicae (13.11\%).

On the other hand, Macrosiphum euphorbiae, Aphis gossypii and M. persicae, were observed on potato leaves. The last two species develop in all potato fields. M. euphorbiae was the most observed in Tizi-Ouzou centre. In Aghribs, $M$. persicae was the most abundant, while in Tizi Rached, A. gossypii was the most abundant (Table 2).

\subsection{DESCRIPTION OF SOME NEW SPECIES}

\subsubsection{Aphis coreopsidis}

Apterae are yellow to green with darker legs, antennae and siphunculi. The abdomen has marginal scleritis (Blackman and Eastop, 2020). The siphunculi are black, relatively long and thick the cauda is clear and narrow

\subsubsection{Capitophorus hippophae}

In spring the apterae colonies are pale green, slender. The alatae are greyish-green with a black head and thorax, dark antennae, legs and siphunculi and a a large quadrate dark green patch on the dorsal abdomen (Blackman and Eastop, 2020). Their primary host are species from the genus Polygonum, and the secondary host are species from the same genus (Remaudière et al., 1985).

\subsubsection{Hyadaphis coriandri}

The alatea are yellow-green in color, dusted with greyish wax. They have short, dusky, slightly swollen, siphunculi. that are about twice as long as wide (Halbert, 2003). This species colonizes Hydrocotyle vulgaris L. (Hydrocotylaceae), Anethum sp. Coriandrum sativum L., Daucus sp. Foeniculum vulgare Mill., Peucedanum sp. 
Table 1:Proportions and relative wealth of aphids trapped in potato fields, the nomenclature of all species is follows that of orders in Fauna Europaea (2020)

\begin{tabular}{|c|c|c|c|}
\hline Aphid species & Tizi-Ouzou Centre & Aghribs & Tizi Rached \\
\hline Acyrthosiphon pisum (Harris, 1776) & $0.76^{*}$ & - & - \\
\hline Anoecia corni (Fabricius, 1775) & 0.13 & - & - \\
\hline Aphis coreopsidis (Thomas, 1878$)^{1}$ & - & - & 0.32 \\
\hline Aphis craccivora Koch, 1854 & 7.51 & 2.6 & 4.2 \\
\hline Aphis fabae Scopoli, 1763 & 9.70 & 11.8 & 8.04 \\
\hline Aphis gossypii Glover, 1877 & 6.87 & 16.41 & 6.8 \\
\hline Aphis idaei van der Goot, 1912 & 3.63 & - & 1 \\
\hline Aphis nerii Boyer de Fonscolombe, 1841 & 2.36 & 0.7 & 1.61 \\
\hline Aphis pseudocardui Theobald, 1915 & - & 0.7 & - \\
\hline Aphis spiraecola Patch, 1914 & 0.95 & 1.1 & 1.3 \\
\hline Aphis sp. & 0.20 & - & 0.32 \\
\hline Aulacorthum solani Kaltenbach, 1843 & 1.78 & 1.52 & 2.6 \\
\hline Brachycaudus cardui (Linnaeus, 1758) & 0.57 & 3 & 1.61 \\
\hline Brachycaudus helichrysi (Kaltenbach, 1843) & 1.65 & 21.8 & 2.3 \\
\hline Brevicoryne brassicae (Linnaeus, 1758) & 2.23 & 1.14 & 0.32 \\
\hline Capitophorus hippophae (Walker, 1852) ${ }^{1}$ & 0.13 & - & - \\
\hline Cavariella aegopodii (Scopoli, 1763) & 0.25 & - & 0.32 \\
\hline Cavariella pastinacae (Linnaeus, 1758) & 0.20 & - & - \\
\hline Cavariella theobaldi (Gillette \& Bragg, 1918) ${ }^{1}$ & 0.13 & - & - \\
\hline Diuraphis noxia (Kurdjumov, 1913) & 0.20 & - & - \\
\hline Dysaphis plantaginea (Passerini, 1860) & 4.39 & 1.14 & 0.64 \\
\hline Dysaphis tulipae (Boyer de Fonscolombe, 1841) & 0.20 & 5.58 & 1 \\
\hline Dysaphis apiifolia (Theobald, 1923) & 0.13 & - & - \\
\hline Dysaphis foeniculus (Theobald, 1923) & - & 1.5 & - \\
\hline Eriosoma lanuginosum (Hartig, 1839) & 0.13 & - & - \\
\hline Hyadaphis coriandri (B. Das, 1918) ${ }^{1}$ & 0.95 & - & - \\
\hline Hyadaphis foeniculi (Passerini, 1860) & 0.57 & - & - \\
\hline Hyalopterus pruni (Geoffroy, 1762) & 0.32 & - & - \\
\hline Hyperomyzus carduellinus (Theobald, 1915) & 0.20 & - & - \\
\hline Hyperomyzus lactucae (Linnaeus, 1758) & 6.17 & 6.4 & 24.44 \\
\hline Hyperomyzus picridis (Börner \& Blunck, 1916) & 0.13 & 1.14 & - \\
\hline Lipaphis erysimi (Kaltenbach, 1843) & 0.95 & 0.76 & 0.64 \\
\hline Macrosiphoniella linariae (Koch, 1855) ${ }^{1}$ & 2.74 & - & - \\
\hline Macrosiphum euphorbiae (Thomas, 1878) & 3.69 & 1.14 & 4 \\
\hline Macrosiphum funestum (Macchiati, 1885) & - & - & 0.4 \\
\hline Macrosiphum rosae (Linnaeus, 1758) & 1.72 & 8.77 & 19.93 \\
\hline Megoura viciae Buckton, 1876 & 1.25 & - & - \\
\hline Metopolophium dirhodum (Walker, 1849) & 0.06 & - & 0.4 \\
\hline Metopolophium festucae Theobald, 1917 & - & 3.1 & - \\
\hline Monelliopsis pecanis Bissell, $1983^{1}$ & 0.13 & - & - \\
\hline Myzocallis castanicola Baker, 1917 & 0.20 & - & - \\
\hline
\end{tabular}




\begin{tabular}{|c|c|c|c|}
\hline \multicolumn{4}{|l|}{ Continued } \\
\hline Myzus ascalonicus Doncaster, 1946 & 2.04 & - & - \\
\hline Myzus cerasi (Fabricius, 1775) & 0.51 & - & - \\
\hline Myzus hemerocallis Takahashi, $1921^{1}$ & 0.13 & - & - \\
\hline Myzus persicae Sulzer, 1776 & 13.11 & 3.1 & 9.00 \\
\hline Myzus sp. & - & - & 0.32 \\
\hline Nasonovia ribisnigri (Mosley, 1841) & 0.45 & - & 0.32 \\
\hline Ovatus crataegarius (Walker, 1850) & - & - & 0.32 \\
\hline Ovatus inulae (Walker, 1849) ${ }^{1}$ & 0.13 & - & - \\
\hline Pemphigus sp. & 1.85 & 0.3 & 1.3 \\
\hline Phorodon humuli (Schrank, 1801) & 0.45 & - & - \\
\hline Pseudoregma panicola (Takahashi, 1921) ${ }^{1}$ & - & 0.7 & - \\
\hline Rhopalosiphum insertum (Walker, 1849) & 0.13 & - & - \\
\hline Rhopalosiphum maidis (Fitch, 1856) & 8.30 & - & 4.50 \\
\hline Rhopalosiphum padi (Linnaeus, 1758) & 7.38 & 6.10 & 1.4 \\
\hline Rhopalosiphum rufiabdominale (Sasaki, 1899) & 0.64 & - & - \\
\hline Rhopalosiphoninus staphyleae (Koch, 1854) ${ }^{1}$ & 0.06 & - & - \\
\hline Schizaphis eastopi Van Harten \& Ilharco, $1971^{1}$ & 0.06 & - & - \\
\hline Schizaphis rotundiventris (Signoret, 1860) & 0.20 & - & - \\
\hline Sipha maydis Passerini, 1860 & - & - & 0.4 \\
\hline Sitobion avenae (Fabricius, 1775) & 0.38 & - & - \\
\hline Sitobion fragariae (Walker, 1848) & 0.70 & - & - \\
\hline Smynthurodes betae Westwood, 1849 & 0.20 & 0.7 & - \\
\hline Takecallis taiwana (Takahashi, 1926) & 0.10 & - & - \\
\hline Uroleucon sonchi (Linnaeus, 1767) & - & - & 0.64 \\
\hline Number of aphid individuals & 1571 & 262 & 311 \\
\hline Number of species & 55 & 24 & 30 \\
\hline
\end{tabular}

${ }^{\star}$ The proportions are expressed in percentage. ${ }^{1}$ Species reported for the first time in Algeria.

Table 2: Proportion and relative abundance of species observed in the three potato fields

\begin{tabular}{lllllll}
\hline \multirow{2}{*}{ Species } & \multicolumn{2}{l}{ Tizi-Ouzou Centre $^{2}$} & Aghribs & & \multicolumn{2}{l}{ Tizi Rached } \\
\cline { 2 - 7 } Aphids $^{\mathrm{a}}$ & Frequency & Aphids $^{\text {a }}$ & Frequency & Aphids $^{\text {a }}$ & Frequency $^{\text {A. gossypii }}$ \\
M. euphorbiae & 492 & $16 \%$ & 64 & $25.4 \%$ & 403 & $67.3 \%$ \\
M. persicae & 2438 & $78 \%$ & - & - & 133 & $22.2 \%$ \\
Total & 196 & $6 \%$ & 188 & $74.60 \%$ & 63 & $10.5 \%$ \\
\hline
\end{tabular}

a: number of aphids. 
Pituranthos sp. Steganotaenia sp. (Umbelliferae) (Remaudière et al., 1985).

\subsubsection{Myzushemerocallis}

Apterae are pale yellowish green or greenish, they measure between 1.6 and $2.4 \mathrm{~mm}$ (Blackman and Eastop, 2020). They attack basal parts of Hemerocallis spp. and Agapanthus umbellatus. L'Herit.

\subsubsection{Pseudoregma panicola}

Apterae are brownish black or dark brownish redviolet, secreting columns of dense white ; the adults measure between 1,1 and 1,9 mm (Blackman and Eastop, 2020). This species colonize underside of bambou leaves Arundinaria alpina K. Schum. (Remaudière et al., 1985).

\subsubsection{Rhopalosiphoninus staphyleae}

In spring, the Apterae on Staphylea are yellowishwhite or pale yellow with a translucent whitish spot on anterior part of dorsal (Blackman and Eastop, 2020). This species lives on Viola tricolor L. (Violaceae).

\subsubsection{Schizaphis eastopi}

The abdomen is devoid of pigmentation, siphunculi are black, cylindrical with apical constriction. The cauda is clear, small than the siphunculi. This species lives on Typha domingensis Pers., Typha angustifolia L. and Typha capensis (Rohrb.) N.E. Br. (Typhaceae) (Remaudière et al., 1985).

\section{DISCUSSIONS}

Based on the trapping results of winged aphids caught using yellow traps installed in three potato fields in the Tizi-Ouzou region, 65 species were identified, after comparison of our results and those of Laamari et al. (2010; 2013), 11 species are new for Algeria, 27 species were collected in Tizi-Ouzou in Draâ Ben Khedda on the bean (Benoufella-Kitous et al., 2014a). BenoufellaKitous et al. (2014b) affirmed the presence of 28 species on citrus fruits in Oued-Aissi (Tizi-Ouzou, Algeria). On the food legumes, 55 species have been recorded in Tala Amara (Tizi-Ouzou) (Benoufella-Kitous et al., 2016) and 43 species in Tizi Rached (Benoufella-Kitous et al., 2019).
Most of these aphid species are pests of cultivated plants, including $M$. persicae, an effective vector, especially of potato viruses. The difference in the specific richness of one region to another can be explained by the difference in the floristic composition which has a direct influence on the aphid richness. Among the plant species recorded in large numbers in the study stations: Picris echioides L., Sonchus oleraceus L., Solanum nigrum L., Malva sylvestris L. and Aven asterilis L. which can host up to 20 aphidian species (Laamari et al., 2010; Moussadegh et al., 2016).

B. helichrysi is the most abundant species in Aghribs with $21.8 \%$. This abundance can be explained by the presence of its primary host plant: thevine crop. The secondary host of this species is represented by the Asteraceae (sow-thistle, lettuce), where it is found in colonies of several individuals living inside of the leaves, sometimes in mixed colonies with Nasonovia ribisnigri (Hullé et al., 1999). In Tizi-Ouzou centre, M. persicae is the most dominant with 206 individuals with a frequency of $13.11 \%$. Similar results have been noted in China by Lopes et al. (2012). These authors highlighted the predominance of this aphid over other captured species. Also in Mali, Yattara et al. (2013), report the presence of this species with $21.2 \%$ on potato. This dominance is explained by the presence of its primary host: the peach tree Prunus persica (L.) Batsch, and also its secondary host which is the potato.

The species $A$. coreopsidis was reported for the first time in Saudi Arabia by Hussain et al. (2015), in spring this species has a several secondary hosts such as Compositae, Asteraceae, Malvaceae and Lamiaceae family (Blackman and Eastop, 2020), and several species of these families are found around the field of Tizi Rached. C. hippophae has as secondary host Polygonaceae such as Polygonum persicaria L. (Forbes and Chan, 1985). The presence of $R$. staphyleae in the Tizi-Ouzou centre is probably due to the presence of flowering plants and also weeds belonging to the Chenopodiaceae family which are secondary hosts of this aphid.

Three species of aphids are found on potato leaves, namely $M$. euphorbiae, A. gossypii and M. persicae. According to Hullé et al. (1999), the latter three species are characteristic of this crop. M. persicae is reported by Laamari and Akkal (2002) in Setif (Algeria). Laamari (2004), in the Guellal region of Biskra (Algeria), notes the presence of $M$. euphorbiae and $M$. persicae on a potato crop. In Kati and Sikasso (Mali), Yattara et al. (2013) highlights the presence of $A$. gossypii and $M$. persicae on this crop for three consecutive years. Lopes et al. (2012) report the presence of the latter two species on potato in China. The difference between the abundance of the three species observed on the leaves of potato crops in all fields, could 
be due to the arrival order of the winged adults, and could be to the competition phenomenon, the aphids can respond differently when they are feeding on the same plant. This dietary variation is related to the capacity of aphid species to encourage the plant to produce a richer diet, especially on amino acid (Telang et al., 1999).

\section{CONCLUSION}

This preliminary study, which focuses on the diversity of aphids associated with potato crop in three localities of the Tizi-Ouzou region (North of Algeria), has shown the existence of 65 species, which 11 species are reported for the first time in Algeria. The presence of aphids and their diversity is favored by the presence of their host plant. In the three study fields several weeds and fruit trees are present, this would explain the abundance of these pests within these fields. Therefore, it would be interesting to continue several studies in different regions, in order to identify the host plants of each aphid species. The identification of their host constitutes an important scientific database in order to contribute to the establishment of an aphid list with trophic relationships (aphid-host plant).

\section{ACKNOWLEDGEMENT}

We would like to thank the three anonymous reviewers for their helpful suggestions and their insightful and constructive critiques.

\section{REFERENCES}

Ahmeid Al-Najar, O.A, \& Nieto Nefrya, K.M. (1998). Notes on Libyan aphids: new recorded species from North Africa. In: J.M Nieto Nefria, Dixon A.F.G (Eds) Aphids in natural and managed ecosystems. Proceedings of the Fifth International Symposium on Aphids, Universidad de Leon (Spain), September 1997, 325-327.

Ahmeid Al-Najar, O.A. (2000). Survey for aphid species in Libya. Arab Journal of Plant Protection, 18(1), 24-27.

Atsebeha, S., Alemu, T., Azerefgne, F., Addis, T. (2009). Population dynamics of aphids and incidence of Ethiopian Pepper Mottle Virus in the central rift valley of Ethiopia. Crop Protection, 28, 443-448. https://doi.org/10.1016/j.cropro.2009.01.007

Autrique, A., and Ntahimpera, L. (1994). Atlas des principales espèces de pucerons rencontrées en Afrique Sub-saharienne. Administration Générale de la Coopération au Développement, AGCD, 78 p.

Ben Halima-Kamel, M. (1991). Contibution à létude de la dynamique des populations aphidiennes en cultures protégées.
Thèse de Doctotat, Faculté des Sciences, Université de Tunis.

Ben Halima-Kamel, M., \& Ben Hamouda, M.H. (1993). Les pucerons des cultures protégées et leurs ennemis naturels. Tropicultura, 11(2), 50-53.

Ben Halima-Kamel, M. (1995). Contribution à l'étude de la dynamique des populations de pucerons en vergers d'agrumes. Bulletin OILB/SROB, 18(5), 39-46.

Ben Halima-Kamel, M., \& Ben Hamouda, M.H. (1998). Contribution à l'étude de la bioécologie des aphides d'une région côtière de la Tunisie. Mediterranean Faculty Landbouw, 63(2a), 365-378.

Ben Halima-Kamel, M., \& Ben Hamouda, M.H. (2004). Aphids of fruit trees in Tunisia. In: J.C Simon, C.A Dedryver, C. Rispe, M. Hullé (Ed.) Aphids in a new millennium. Proceedings of the VIth International Symposium on Aphids, Paris, 119-123.

Ben Halima-Kamel, M., \& Ben Hamouda, M.H. (2005). A propos des pucerons des arbres fruitiers de Tunisie. Notes faunistiques de Gembloux,58, 11-16.

Benoufella-Kitous, K., \& Medjdoub-Bensaad, F. (2016). Aphid's diversity in chickpea (Cicer arietinum) and lentil (Lens culinaris) cultures within Tala Amara region (Tizi-Ouzou, Algeria). Advances in Environmental Biology, 10(8), 19-29.

Benoufella-Kitous, K., Doumandji, S., Hance, T. (2014b). Inventaire des aphides et leurs ennemis naturels dans un verger d'agrumes. Deuxième conférence internationale sur les ravageurs en agriculture, AFPP, Montpellier, 22 et 23 octobre.

Benoufella-Kitous, K., Doumandji, S., Medjdoub-Bensaad, F. (2014a). Interest and place of three Vicia faba aphids species in Draâ Ben Khedda (Great Kabylia, Algeria). International Journal of Agricultural Science and Research, 4(6), 27-36.

Benoufella-Kitous, K., Medjdoub-Bensaad, F., Kheloul, L. (2019). Diversité des pucerons des légumineuses alimentaires dans la région de Tizi-Ouzou. Entomologie Faunistique, 72, 5-12.

Blackman, R.L., \& Eastop, V.F. (1994). Aphids on the world's trees. An Identification and Information guide. CAB International, Wallingford, $987 \mathrm{p}$.

Blackman, R.L., \& Eastop, V.F. (2000). Aphids on the world's crops. An Identification and Information guide. The Natural History Museum, London, 466 p.

Blackman, R.L., \& Eastop, V.F. (2006). Aphids on the World's Herbaceous Plants and Shrubs. Ltd JWS (ed.), The Natural History Museum, London, 1439 p.

Blackman, R.L., \& Eastop, V.F. (2020). Aphids of the world's plants: an online identification and information guide. [online] URL: http://www.aphidsonworldsplants.info (Accessed November 27, 2020).

Bodenheimer, F.S., \& Swirski, E. (1957). The Aphidoidea of the Middle East. Weizmann Science Press of Israel, Jerusalem, 378 pp.

Boukhris-Bouhachem, S., Jerraya, A., Boudhir, H. (1996). Etude préliminaire sur la présence des espèces aphidiennes en verger d'Agrumes (Cap bon, Tunisie). Annales d'INRA Tunis, 69, 55-72.

Boukhris-Bouhachem, S., Souissi, R., Turpeau, E., Rouzé Jouan, J., Fahem, M., Hullé, M. (2007). Aphid (Hemiptera, Aphi- 
doidea) diversity in Tunisia in relation to seed potato production. Annales de la Société Entomologique de France, 43(3), 311-318. https://doi.org/10.1080/00379271.2007.10 697526

Brillaud, R. (2008). La pomme de terre peut-elle sauver le monde ? Science et vie, 96-101.

Damiano, A. (1961). Elenco delle specie di insetti dannosi ricordat per la Libia al 1960 fin al 1960. Nazirato dell'Agricoltura Tripolitania, Tripoli, $81 \mathrm{pp}$.

Damiano, A. (1962). Rassegna dei principli casi entomologici osservati in Tripolitania nel 1960. Rivista Di Agricoltura Subtropicale E Tropicale Annale, 56(1/3), 21-36.

Darwish, E.T.E. (2009). Studies on maize's aphids ecology and taxonomy in Egypt. Journal of Applied Entomology, 107(1/5), 155-159. https://doi.org/10.1111/j.1439-0418.1989. tb00244.x

EDES, 2012. Méthodes d'observation et d'échantillonnage au champ des populations de ravageurs. Surveillance et contrôle des bio-agresseurs dans les cultures. Cahier technique R.5 : 29.

Forbes, A.R., \& Chan, C.K. (1985). The aphids (Homoptera: Aphididae) of British Columbia 13. further additions. Journal of the Entomological Society of British Columbia, 82, 5658.

Habib, A., El Kady, E.A. (1961). The Aphididae of Egypt. Technical Science Service, Scope Ministry of Agriculture. Egypt Bulletin, 68, 1-62.

Halbert, S. E. (2003). Hyadaphis coriandri (Das) (Insecta: Hemiptera: Aphididae). Featured Creatures. http://entnemdept.ufl.edu/creatures/veg/aphid/coriander_aphid.htm (Reviewed: December 2017/ Acced: 27/11/2020.

Hidalgo, N.P., Bouhraoua, R., Boukreris, F., Benia, F., Khelil, M.A., Villar, J.P. (2012). New aphids records (Hemiptera: Aphididae) from Algeria and the Northern Africa. Redia, 31-34.

Hullé, M., Ighil, E.T.A., Robert, Y., Monnet, Y. (1999). Les pucerons des plantes maraîchères. Cycles biologiques et activités de vol. I.N.R.A., Paris, $136 \mathrm{p}$.

Hussain, S., Aldryhim, Y., Al-Dhafer, H., Halbert, S., Thomas, J. (2015). New aphid records for Saudi Arabia (Hemiptera: Aphidoidea). Zoology in the Middle East, 61(4), 368-371. https://doi.org/10.1080/09397140.2015.1101927

Jacky, F., \& Bouchery, Y. (1982). Atlas des formes ailées des espèces courantes de pucerons. Institut National de la Recherche Agronomique, Colmar, $48 \mathrm{p}$.

Laamari, M. (2004). Etude éco-biologique des pucerons des cultures dans quelques localités de l'Est Algérien. Thèse de doctorat d'état en agronomie, Ecole Nationale Supérieure d'Agronomie (ENSA), Alger. 204 p. https://doi.org/10.1111/ epp. 12323

Laamari, M. (2016). First report of Phylloxera quercus (Hemiptera: Sternorrhyncha: Aphididae) in Algeria. Bulletin OEPP, 46(3), 1-4.

Laamari, M., \& Akkal, Y. (2002). Aphid population dynamics and the rate of virus diseases in potato fields in the Setif region of Algeria. Arab Journal of Plant Protection, 20(2), 111-117. https://doi.org/10.1111/epp.12284

Laamari, M., Aggoun H., Stary P., Cœur D’Acier, A. (2016).
First report of Siphonatrophia cupressi and its parasitoids in Algeria and a first for Africa. Bulletin OEPP, 46(1), 122-124.

Laamari, M., Cœur D’Acier, A., Joussellin, E. (2013). New data on aphid fauna (Hemiptera, Aphididae) in Algeria. ZooKeys, 319, 223-229. https://doi.org/10.3897/zookeys. 319.4340

Laamari, M., Cœur D’Acier, A., Joussellin, E. (2010). Assesment of aphid diversity (Hemiptera: Aphididae) in Algeria: afourteen-year investigation. Faunistic Entomolgy, 62, 73-87.

Lascaux, E. (2010). Lutte biologique contre les pucerons : auxiliaires, stratégies et perspectives en cultures maraîchères et en fraise. Journées techniques Fruits et Légumes Biologiques, 33-37.

Leclant, F. (1999). Les pucerons des plantes cultivées. Clefs d'identification des Grandes Cultures. Ed. Inst. nati. rech. agro., Montpellier, $98 \mathrm{p}$.

Lin, F.J., Bosquée, E., Liu, Y.J., Chen, J.L., Yong, L., Francis, F. (2016). Impact of aphid alarm pheromone release on virus transmission efficiency: When pest control strategy could induce higher virus dispersion. Journal of Virological Methods, 235, 34-40. https://doi.org/10.1016/j.jviromet.2016.05.009

Lopes, T., Bosquée, E., Polo Lozano, D., Chen, J.L., Deng Fa, C., Yong, L., Fang-Qiang, Z., Haubruge, E., Bragard, C., Francis, F. (2012). Evaluation de la diversité des pucerons et de leurs ennemis naturels en cultures maraîchères dans l'est la Chine. Entomologie Faunistique, 64(3), 63-71.

Marchoux, G., Gognalons, P. Gébré-Sélassié, K. (2008). Virus des Solanacées Du génome virale à la protection des cultures. Quae. I.N.R.A, Versailles, 843 p.

Moussadegh, M.S., Stary, P., Sharaf, M., Mohammadi, S., Ldawood, A.S., Tamoli Torfi, E., Abolfarsi, R., Bahrami, R., Mohseni, L., Shahini, A., Seifollahi, F., Soheilyfar, P., Ravan, B., Alaghemdani, A. (2016). Aphid-ant-parasitoid and host plant associations in drylands of Khuzestan, Iran (Hemiptera : Aphidae; Hymenoptera : Formicidae ; Hymenoptera : Braconidae: Aphidiinae). Entomologist's Monthly Magazine, 152, 289-294.

Mier Durante, M. P., Eastop, V., Rakauskas, R., Remaudiere, G., Nieto Nafria, J.M., Heie O. (2020). Fauna Europaea Family Aphididae. version 2017.06, https://fauna-eu.org (accessed 10 December 2020).

Remaudière, G., \& Remaudière, M. (1997). Catalogue des Aphididae du monde. Catalogue of the world's Aphididae (Homoptera, Aphididae). INRA, Paris, $376 \mathrm{p}$.

Remaudière, G., Autrique, A., Eastop, V.F., Stary, P., Aymonin, G. (1985). Contribution à l'écologie des aphides africains. Organisation des Nations Unies pour l'alimentation et l'agriculture, Rome, $214 \mathrm{p}$.

Sekkat, A. (2015). Les pucerons au Maroc : abrégé bioécologique des espèces évoluant sur les cultures. Revue Marocaine de Protection des Plantes, 7, 1-23.

Shi, X., Gao, Y., Yan, S., Tang, X., Zhou, X., Zhang, D., Liu, Y. (2016). Aphid performance changes with plant defense mediated by Cucumber mosaic virus titer. Virology journal, 13(70), 1-7. https://doi.org/10.1186/s12985-016-0524-4

Stroyan, H.L.G. (1961). La détermination des aphides vivant 
sur Citrus. Bulletin phytosanitaire, Food and Agricultural Organisation, 9(4), $45-68$.

Tellang, A., Sandström J, Dyreson E., Moran, N.A. (199). Feeding damage by Diuraphis noxia results in a nutritionally enhanced phloem diet. Entomologia Experimentalis et Applicata, 91, 403-412. https://doi.org/10.1046/j.15707458.1999.00508.x

Theobald, F.V. (1922). New Aphididae found in Egypt. Bulletin Society Royaume Entomology of Egypt, 6, 39-80.
Trotter, A. (1912). Contributo alla conoscenza delle galle tripolitana. Marcellia, 11, 116-210.

Trotter, A. (1914). Nuovo contributo alla conoscenza delle galle tripolitana. Marcellia, 13, 3-18.

Yattara , A.A.A., Coulibaly, A.K., Francis, F. (2013). Diversité et abondance des pucerons (Homoptera : Aphididae) et leur impact sur la dissémination des virus infectant la pomme de terre au Mali. Phytoprotection, 94(1), 1-7. https://doi. org/10.7202/1024719ar 